\title{
The Relationship between Human Papillomavirus and Epstein-Barr Virus Infections with Breast Cancer of Iranian Patients
}

Zahra Tahmasebi Fard ${ }^{1}$

${ }^{1}$ Assistant Professor, Department of Biology, Roudehen Branch, Islamic Azad University, Roudehen, Iran.

Received: 20 Sep 2013

Revised : 22 Oct 2013

Accepted: 18 Nov 2013

Corresponding Authors:

Zahra Tahmasebi Fard

Department of Biology, Roudehen

Branch, Islamic Azad University,

Roudehen, Iran.

E-mail: ztahmasebifard@yahoo.com

\begin{abstract}
Background: As the etiology and progression of breast cancer remain incompletely understood, novel routes of disease pathogenesis are important to consider. Some researchers have been found Human papillomavirus (HPV) and Epstein Barr virus (EBV) in breast carcinomas (BCs).

Materials and Methods: Paraffin-embedded sections from 65 female patients with breast carcinoma and 53 breast tissues from patients with fibrocystic disease as control were selected. After DNA extraction and amplification of housekeeping gene (beta-globin), all suitable samples were evaluated for presence of DNA-EBV and DNA-HPV by using PCR (Polymerase Chain Reaction).

Results: HPV DNA sequences were detected in 3 of the 53 benign breast tissue samples but none of the breast carcinoma samples was identified. EBV was detected by PCR in 23 of 65 (35.38\%) cases of breast cancer specimens and 11 of $53(20.75 \%)$ control samples (fibroadenoma 7 of $26(26.92 \%)$ and fibrocystic 4 of $27(14.81 \%))$. A total of 118 samples from 34 cases (81/28\%) were positive. Statistically, crammer indicator analysis for EBV infection in tumor samples and normal samples was 0.46 which indicates a significant relationship.

Conclusion: Our analysis could not confirm a role of HPV in breast cancer but statistically, significant correlation between EBV infection and breast cancer exists. To demonstrate the possible relationship between viral load and breast cancer, need for epidemiological, biological and molecular mechanisms to clear the virus is involved in the process of carcinogenesis.
\end{abstract}

Keywords: Human Papillomavirus (HPV); Epstein Barr virus (EBV); Breast cancer; PCR

Please cite this article as: Tahmasebi Fard Z. The Relationship between Human Papillomavirus and Epstein-Barr Virus Infections with Breast Cancer of Iranian Patients. Res Mol Med. 2013; 1 (3): 38-42

\section{Introduction}

Breast cancer is the most common malignancy in the world. Researchers have focused primarily on reproductive and other factors affecting circulating sex hormones and on genetic susceptibility (1). Though, these factors can explain just fifty percent of breast cancer, the researchers to look for other environmental factors such as viral etiology (2). Viruses such as Epstain-Barr virus and Human papilloma virus are known to be associated with some human malignant (3).

High risk human papillomavirus (HR-HPVs) are carcinogenic viruses which are primarily associated with cervical cancer but are also linked with other anogenital cancers and cancers of other organ sites, such as oral cavity, esophagus, nasopharyngeal and laryngeal carcinoma and possibly in retinoblastoma (4) based on their oncogenic potential (5). Correlation of DNA identification of HPV and breast cancer ranges in variability from $0-86 \%$ of cases but the mechanism by which the virus reaches the breast has not been clearly identified (6).

Epstein-Barr virus (EBV) infects almost all of the world's adult population and establishes a lifelong persistence (7). EBV is associated with nasopharyngeal carcinoma and Burkitt's lymphoma, and has been involved in the development of a subset of gastric 
cancer and breast cancer (8). The evidence for an association between EBV and breast cancer has been reported in the worldwide. According to the reports of the presence of EBV and HPV in breast cancer, we decided to determine the existence of these two viruses in breast cancer. We tested the breast cancer samples and normal breast tissues by PCR for presence of these viruses.

\section{Materials and Methods}

Patients and specimen collection

All patients were selected from the Imam Khomeini and Sizdah Aban Hospitals. From all paraffin blocks were chosen, slides that reviewed by two pathologists. After confirming, the clinical information was retrieved from the clinical file, such as: Age at diagnosis and histological reports. Tumor samples were typed according to the American Joint Committee on Cancer included: 47 invasive ductal carcinomas, 12 invasive lobular, 4 papillary, 1 tubular, 2 mucinous and 1 aprocrine. In overall, Sixty seven cases of malignant breast lesion and fifty three of non malignant breast lesions were used as controls (26 sample of fibroadenoma and 27 samples of fibrocystic diseases).

Table 1. List of Primers sequences

\begin{tabular}{|c|c|c|c|c|}
\hline Name & Primers & Primer Sequences & Annealing temperature $\left({ }^{\circ} \mathrm{C}\right)$ & Amplimer size (bp) \\
\hline Beta globin gene & $\begin{array}{l}\mathrm{GH} 20 \\
\mathrm{PCO} 4\end{array}$ & $\begin{array}{l}\text { 5'- GAAGAGCCAAGGACAGGTAC -3' } \\
\text { 5'-CAACTTCATCCACGTTCACC -3' }\end{array}$ & $55^{\circ} \mathrm{C}$ & $250 \mathrm{bp}$ \\
\hline HPV & $\begin{array}{l}\text { GP5+ } \\
\text { GP6+ }\end{array}$ & $\begin{array}{l}\text { 5'-TTTGTTACTGTGGTAGATACTAC- } \text { 3' }^{\prime} \\
\text { 5'-CTTATACTAAATGTCAAATAAAAA-3' }\end{array}$ & $40{ }^{\circ} \mathrm{C}$ & $145 \mathrm{bp}$ \\
\hline EBV & $\begin{array}{l}\text { LMP1 } \\
\text { LMP1 }\end{array}$ & $\begin{array}{l}5^{\prime} \text { AGT CTG GGA AGA CAA CCA CA 3' } \\
5^{\prime} \text { CCC GCC TAC ACA CCA ACT AT 3' }\end{array}$ & $60^{\circ} \mathrm{C}$ & $210 \mathrm{bp}$ \\
\hline
\end{tabular}

Deparaffinizing and DNA isolation

Ten $10-\mu \mathrm{m}$-thick sections were cut from (formalin fix paraffin embedded) FFPE tissues. After every sample, the knife was cleaned with xylene and ethanol. Deparaffinizing the samples was done using Xylene/ethanol. In brief, $1000 \mu \mathrm{l}$ xylen (Merck Company, Germany) was added to $10 \mu \mathrm{m}$ sections, agitated, heated for $15 \mathrm{~min}$ at $37{ }^{\circ} \mathrm{C}$ then spun at $10000 \mathrm{~g}$ for $15 \mathrm{~min}$. The supernatant was removed, fresh xylene added, and these steps repeated two times. Two identical washes with $100 \%$ ethanol (Merck Company, Germany) for $30 \mathrm{~min}, 37{ }^{\circ} \mathrm{C}$, spinning at $10000 \mathrm{~g}$ for $15 \mathrm{~min}$, was followed by air drying of the tissue pellet before digestion . Digestion was performed by adding $150 \mu \mathrm{l}$ of digestion buffer (Tris- $\mathrm{HCl} 100 \mathrm{mM} \mathrm{pH}=7.5$, Tween $200.05 \%$ and Proteinase $\mathrm{K} 3 \mu \mathrm{l}$ of $10 \mathrm{mg} / \mathrm{ml}$ (Fermentase) to each tube and digested for overnight at $55{ }^{\circ} \mathrm{C}$. Proteinase $\mathrm{K}$ was inactivated at $92^{\circ} \mathrm{C}$ for $10 \mathrm{~min}$.

DNA was extracted by the DNeasy Tissue Kit (QIAGEN, Hilden, Germany) according to manufacturer's protocol. Quality of isolated DNA was checked by spectrophotometer and PCR

\section{Sample suitability}

Suitability of samples for PCR amplification was ascertained by testing for the beta-globin gene. Successful amplification of the beta-globin gene fragments indicated that the DNA sample was adequate for PCR analysis and that no PCR inhibitors were present.

Beta-globin gene amplification

After DNA extraction, all samples were amplified for beta globin gene by GH20 \& PCO4 primers. To the reaction mixture were prepared $20 \mathrm{ml}$ for each sample. Initially, they were heated at $95{ }^{\circ} \mathrm{C}$ for $5 \mathrm{~min}$ and then 40 cycles of PCR, including the demolition process at $95{ }^{\circ} \mathrm{C}$ for $30 \mathrm{~s}, 66^{\circ} \mathrm{C}$ for $40 \mathrm{~s}$, and primer binding fragment elongation at $72{ }^{\circ} \mathrm{C}$ for 40 seconds were and at the end of a cycle at $72{ }^{\circ} \mathrm{C}$ for $5 \mathrm{~min}$. To confirm of $250 \mathrm{bp}$ bands, the PCR products were observed on $1 / 5 \%$ agarose gel electrophoresis by ethidium bromide staining and UV photography (Uvidoc, BTS-20-M, EEC).

\section{Amplification for $E B V$}

To determine the presence, physical status of EBV, PCR was performed. Master mixtures contained PCR buffer, $10 \mathrm{mmol} / \mathrm{L}$ Tris-HCl (pH 8.4), $50 \mathrm{mmol} / \mathrm{L}$ $\mathrm{KCl}, 2.5 \mathrm{mmol} / \mathrm{L} \mathrm{MgCl} 2,0.01 \%$ gelatin, $0.2 \mathrm{mmol} / \mathrm{L}$ of each dNTP (dATP, dCTP, dGTP and dTTP), 0.5 $\mathrm{mmol} / \mathrm{L}$ of each primer, 100ng DNA and 1.5 units of Taq polymerase (Amp Taq). The PCR mixture was subjected to 40 cycles of amplification (using Genius thermal cycler) each consisting of an initial denaturing step at 94 for $30 \mathrm{~s}$, annealing at 60 for $30 \mathrm{~s}$ and extension at 72 for 30 s that amplified a $210 \mathrm{bp}$ of viral genome. Distilled water was used as a negative control. Then the PCR products were detected by $2 \%$ 
agarose gel electrophoresis and visualized by ethidium bromide staining. Results were saved by a documentation system along with a transilluminator.

\section{Amplification for $\mathrm{HPV}$}

The presence of HPV DNA sequences was analyzed by GP5+ \& GP6+ primers. The consensus primers GP5+ and GP6+ generate 140 fragment of the L1 region of broad spectrum of HPV types (9). Briefly, the amplification was performed in $25 \mu 1$ master mix, containing $0.5 \mathrm{mmol} / \mathrm{L}$ of each of GP5+ and GP6+ primers, PCR buffer $\{10 \mathrm{mmol} / \mathrm{L}$ Tris- $\mathrm{HCl}(\mathrm{pH} 8.4)$, $50 \mathrm{mmol} / \mathrm{L} \mathrm{KCl}, 2.5 \mathrm{mmol} / \mathrm{L} \mathrm{MgCl} 2,0.01 \%$ gelatin $0.2 \mathrm{mmol} / \mathrm{L}$ of each dNTP (dATP, dCTP, dGTP and dTTP), 100ng DNA and 1.5 units of Taq polymerase (Amp Taq).The amplification ramp included first step for $3 \mathrm{~min}$ at $95{ }^{\circ} \mathrm{C}$ for initial denaturation, followed by denaturation cycle of $20 \mathrm{sec}$ at $95{ }^{\circ} \mathrm{C}$, an annealing cycle of $15 \mathrm{sec}$ at $40^{\circ} \mathrm{C}$ and an elongation and readout cycle of $30 \mathrm{sec}$ at $72^{\circ} \mathrm{C}$ for 40 cycles. The amplified products were visualized on $1.5 \%$ agarose gels.

\section{Results}

The Mean \pm SD age of women participating in the study was 53.2 \pm 12 years in cases (range 32-71 years), and 51.6 \pm 10.3 years in controls (range 35-63 years). After DNA extraction, two samples (from cancerous tissues) were found unsuitable for PCR and excluded. (Figure 1)

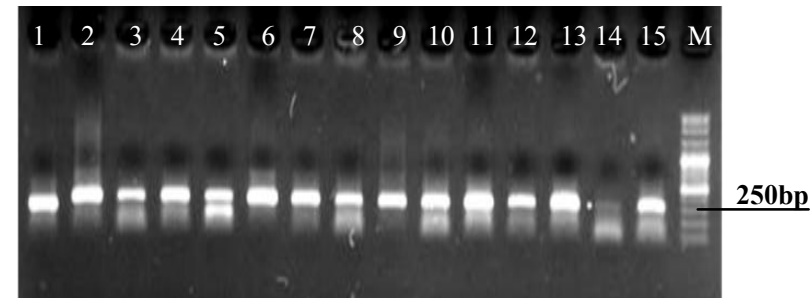

Figure 1. PCR amplification of beta globin gene showing 250bp. Electroforetical analysis of PCR products. Line M: MW marker, lines marked 1-15 are DNA extraction from normal Tissues and cancerous samples.

EBV was detected by PCR in 23 of $65(35.38 \%)$ cases of breast cancer specimens and 11 of $53(20.75 \%)$ control samples (fibroadenoma 7 of $26(26.92 \%)$ and fibrocystic 4 of 27 (14.81\%)). A total of 118 samples of 34 cases $(28 / 81 \%)$ were positive (Figure 2 ).

HPV DNA sequences wasn't detected in benign breast tissue samples and none of the breast carcinoma samples by using primers located within the conserved L1 region of HPV genome.

\section{Discussion}

Probability that the virus could have a role in the etiology of breast cancer was first proposed in 1936 by Bittner et al. They are found in mouse milk unknown factors could cause breast cancer in adulthood. Mouse mammary tumor virus was later named this unknown factor (7). Breast cancer is a multistep disease that one of these multistep processes, pathogenic viruses may have a role (10). Whereas, viruses involved in the development of various cancers (1) the physiopathology of viral etiology in breast cancer has been proposed .In addition to numerous theories about infectious agents has been proposed that could be induction of cancer by suppressing the immune system and be effect on either direct or indirect to oncogenes (11).

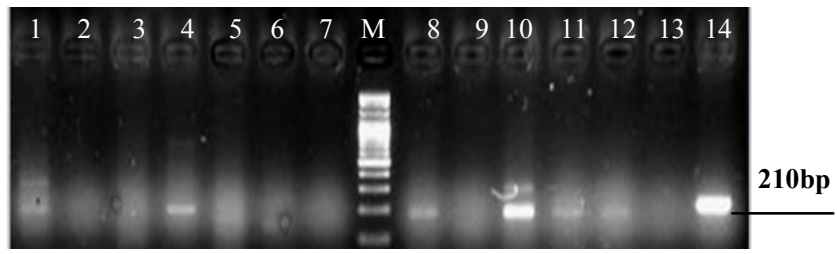

Figure 2. PCR amplification of LMP1 gene for EBV.

Electroforetical analysis of PCR products. Line 1 and Line 4: Positive samples of normal tissue Line 2, 3, 5\&6 Negative samples of normal tissue. Line 7: Negative control, Line M: MW marker, lines marked $8,10,11, \& 12$ are Positive samples of cancerous tissue. Line 14: Positive control (PCR product size $210 \mathrm{bp}$ ).

The etiological role of HPV and EBV in some extragenital tumors is under intense debate (12).

We purposed to determine prevalence of HPV and EBV in breast cancer of Iranian patients.

Since, the evaluation of EBV in breast cancer based on viral proteins is not valid because of the extremely low EBV viral loads and the latency of EBV with minimal protein expression (7). Therefore, we used the PCR method for detection of DNA sequences of these viruses. Our finding showed that the lack of HPV in breast cancer indicates that the virus has not etiological role in breast carcinogenesis of Iranian women. But statistically, significant correlation between EBV infection and breast cancer was existed. The results of this study for EBV are similar to results obtained by other researchers such as Mazouni (33/2\% of positive cases detected) (11) Serene Perkins (46\% were positive) (13), Mathilde Bonnet (in $51 \%$ of tumors positive identification) and even Hratch Arbach has been calculated the number of copies of the EBV genome in breast cancer specimens (14). We checked twenty-two studies that carried out in this area based on polymerase chain reaction (PCR) analyses: EBV sequences were identified in 18 of these studies and five of the studies were based on immunohistochemistry (IHC) and/or in situ hybridization techniques (ISH); EBV was not identified in any of these studies (7).

Human papillomaviruses (PVs) are small doublestranded DNA viruses that infected different areas of the squamous epithelium (15). High risk HPV has 
been formally recognized as being causal in cervical cancers. Some researchers had reported that HPVs may also have a role in breast cancer. Clinical studies are controversial data about the presence of HPV in breast cancer. European studies have mainly focused on the types of HPV 16 and 18, while data from Japanese and Chinese women, breast cancer is associated with evidence of HPV types such as HPV33 (16). Our results for HPV was similar to other results that couldn't be detected virus in the breast cancer such as Hachana (from 123 sample of Tunisian patients) (17), Lindel (from 81 sample of swiss patients) (18), Hedau (from 252 sample of indian patients) (19), CremouxP (from 50 sample of Francis patients) (20). But other researchers were reported to identify HPV in breast cancer in a range of populations including Australia, Italy, Norway, China, Japan, USA, Austria, Brazil, Taiwan, Turkey, Greece, Korea, Mexico, Hungary and Syria (7). In contrast to cervical cancer, HPV is difficult to detect in breast cancer may be ,because of low levels of HPV DNA sequences in breast cancer or due to differences in laboratory methods.

Due to the high sensitivity of technique PCR that was used in the present study, our results showed that the genome HPV wasn't in tumor samples and normal tissues. Probably HPV induced cancer by mechanisms "hit and run". According to a report in 1987 by the campo, the papillomavirus are used mechanism of hit and run to induce esophageal cancer. Their study on bovine papilloma virus that rendered models in the early stages of carcinogenesis in the gut of cattle, but for the progression to malignancy cases, their presence is not necessary. (21).

\section{Conclusion}

Our analysis could not confirm a role of HPV in breast cancer of Iranian patients. But about EBV are similar to those reported in the world, in which prevalence of between 30 and $50 \%$ is suggested in the association of invasive breast cancer and EBV infection. Most epidemiological, biological and molecular studies is necessary to clear mechanisms involved the virus in the process of carcinogenesis.

\section{Acknowledgements}

I am thankful to Dr Abdirad, Dr Saatian and Dr Arefian for their cooperation to selection appropriate samples. The financial aid for this project has been provided by the Research Council of Roudehen University.

\section{References}

1. Sally L Glaser, Joe L, Hsu and Margaret L. Gulley. Epstein-Barr Virus and Breast Cancer: State of the Evidence for Viral Carcinogenesis. Cancer Epidemiol Biomarkers Prev. 2004; 13: 688-97. PMID: 15159298
2. Deepti Joshi, Munira Quadri, Neha Gangane, Rajnish Joshi, Nitin Gangane. Association of Epstein Barr Virus Infection (EBV) with Breast Cancer in Rural Indian Women. PLoS ONE. 2009; 4 (12): e8180. PMID: 19997605

3. Gumus M, Yumuk PF, Salepci T, Aliustaoglu M, Dane F, Ekenel M, et al. HPV DNA Frequency and subset analysis in human breast cancer patients normal tumoral Tissue samples. J Exp Clin Cancer Res. 2006; 25 (4): 515-21. PMID: 17310842

4. Hedau S, Kumar U, Hussain S, Shukla S, Pande S, Jain N, et al. Breast cancer and human papillomavirus infection: No evidence of HPV etiology of breast cancer in Indian women. BMC Cancer. 2011; 11 (27); 1-10. PMID: 21247504

5. Schobert D, Remy V, Schoeffski O. Cost-effectiveness of vaccination with a quadrivalent HPV vaccine in Germany using a dynamic transmission model. Health Econ Rev. 2012; 2 (1): 19. PMID: 23009387

6. de León DC, Montiel DP, Nemcova J, Mykyskova I, Turcios E, Villavicencio V, et al. Human Papillomavirus (HPV) in breast tumors: prevalence in a group of Mexican patients. BMC Cancer. 2009; 9:26. PMID:19161629

7. James S. Lawson and Benjamin Heng. Viruses and Breast Cancer .Cancers. 2010; 2: 752-72.

8. Glaser SL, Hsu JL, Gulley ML. Epstein-Barr virus and breast cancer: state of the evidence for viral carcinogenesis. Cancer Cancer Epidemiol Biomarkers Prev. 2004; 13:688-97. PMID:15159298

9. Sotlar K, Diemer D, Dethleffs A, Hack Y, Stubner A, Vollmer $\mathrm{N}$, et al. Detection and typing of human papillomavirus by E6 nested multiplex PCR. J Clin Microbiol. 20; 42 (7): 3176-84. PMID: 15243079

10. Louise G, Labrecque, Diana M. Barnes, Ian S. Fentiman, and Beverly E. Griffin. Epstein-Barr Virus in Epithelial Cell Tumors: A Breast Cancer Study. Cancer Res. 1995; 55(1): 39-45. PMID: 7805038

11. Mazouni C, Fina1F, Romain S, Ouafik L, Bonnier P, Brandone $\mathrm{J}-\mathrm{M}$, et al. Epstein-Barr virus as a marker of biological aggressiveness in breast cancer. Br J Cancer. 2011; 104: 332-7. PMID: 21179039

12. Aguayo F, Khan N, Koriyama C, González C, Ampuero S, Padilla $\mathrm{O}$, et al. Human papillomavirus and Epstein-Barr virus infections in breast cancer from chile. Infect Agent Cancer. 2011; 6(1):7. PMID: 21699721

13. Perkins RS, Sahm K, Marando C, Dickson-Witmer D, Pahnke GR, Mitchell M, et al. Analysis of Epstein-Barr virus reservoirs in paired blood and breast cancer primary biopsy specimens by real time PCR. Breast Cancer Res. 2006; 8 (6): R70. PMID: 17163997

14. Arbach H, Viglasky V, Lefeu F, Guinebretière JM, Ramirez V, Bride Net al. Epstein-Barr Virus (EBV) Genome and Expression in Breast Cancer Tissue: Effect of EBV Infection of Breast Cancer Cells on Resistance to Paclitaxel (Taxol). J Virol. 2006; 845-53. PMID: 16378986

15. E.M. de Villiers. Taxonomic classification of papillomaviruses. Papillomavirus Rep. 2001; 12: 57-63.

16. Lindel K, Forster A, Altermatt HJ, Greiner R, Gruber G. Breast cancer and human papillomavirus (HPV) infection: No evidence of a viral etiology in a group of Swiss women. Breast. 
2007; 16(2): 172-7. PMID: 17088061

17. Hachana M, Ziadi S, Amara K, Toumi I, Korbi S, Trimeche M. No evidence of human papillomavirus DNA in breast carcinoma in Tunisian patients. Breast. 2010; 19(6): 541-4. PMID: 20547456

18. Lindel K, Forster A, Altermatt HJ, Greiner R, Gruber G. Breast cancer and human papillomavirus (HPV) infection: No evidence of a viral etiology in a group of Swiss women. Breast. 2007; 16(2): 172-7. PMID: 17088061

19. Hedau S, Kumar U, Hussain S, Shukla S, Pande S, Jain N, et al. Breast cancer and human papillomavirus infection: No evidence of HPV etiology of breast cancer in Indian women. BMC Cancer. 2011; 11: 27. PMID: 21247504
20. de Cremoux P, Thioux M, Lebigot I, Sigal-Zafrani B, Salmon R, Sastre-Garau X. Institut Curie Breast Group. Breast Group. No evidence of human Papillomavirus DNA sequences in invasive breast carcinoma. Breast Cancer Res Treat. 2008; 109 (1): 55-8. PMID: 17624590

21. Campo MS. Papillomas and cancer in cattle. Cancer. Surv. 1987; 6: 39-54. 